\title{
Study on Occupation Quality Education of Law Undergraduates Rong-Xia ZHANG
}

\author{
School of Law, Beihua University, Jilin, China, 132013
}

E-mail: zhangrx55@163.com

Keywords: Law; Undergraduate; Occupation Quality Education

\begin{abstract}
Undergraduate education of law is a kind of occupation education, so the education goal is to develop occupational legal talents with high quality for the society. The occupation accomplishment that law undergraduate should have, including not only grasp the basic theory of law enough, but also have strong legal thinking and strong practical ability. In order to enhance the law students' occupation quality, we should focus on strengthening the practice teaching.
\end{abstract}

\section{The Importance of Occupation Quality Education for Law Undergraduates}

University education is divided into different levels, and each level of training objectives should be different. As a legal professional undergraduate training objectives, the correct orientation should be the cultivation of applied talents, so that graduate students can be engaged in grassroots legal occupation activities, which requires us to cultivate the undergraduates should have applied legal talents with higher quality of legal occupation.

\section{Strengthen the Legal Occupation Quality Education Conform to the Goal Orientation of Law Undergraduate Education}

The stage of undergraduate education is to develop students' basic law stage of legal literacy, so the undergraduate education of law should ensure that construct the complete system of legal theory of knowledge in the minds of students, and form the legal thinking. The undergraduate education of law "is not only to impart legal knowledge and methods, but also lies in the cultivation of the spirit of law and the rule of law belief, master the methods of legal thinking and using legal language and so on." [1] The cultivation of legal thinking of students is the primary goal of undergraduate education of law. In the process of legal thinking of teaching, strengthen the practice teaching of law majors, to realize the theory to guide the practice and make the theory sublimate in practice. Of course, the function of legal education not only lies in the cultivation of legal talents that useful for the society, is also lies in thought to the social dissemination of legal knowledge and legal. [2]Under the guidance of Chinese overall goal of legal education, Legal education at different levels should play different educational objectives. Undergraduate education as the most important and basic legal education with which the social main task is: first, the cultivation of professional talent that the legal community of law occupation need; second, train some inter-disciplinary talent that master some knowledge of law; third, cultivate the legal consciousness of citizens.

\section{To Cultivate Applied Legal Talents We Should Strengthen the Legal Occupation Quality Education}

The work of the judicial practice is a kind of work that based on legal education and practical experience. And this experience we can acquire and understand in the process of legal occupation. "In spite of the Scientific and academic of Chinese legal education has become the mainstream, but the legal education that separate oneself from the legal occupation, its main purpose will no longer exist. Moreover, Legal Education without the legal occupation, it has been or will lose the right direction." [3]Therefore, in order to maintain long-term vitality and constantly to cultivate and delivery legal talents of fitting for the needs of the society, as the basic stage of legal education, undergraduate education of law must do well in effective cohesion between the education of law and legal occupation. The basic premise of the work is to fully realize the undergraduate education of law should be a kind of occupation education. As a kind of occupation education, the 
undergraduate education of law should cultivate students' occupation quality, so that students are able to become qualified talents to meet the social needs.

\section{The Professionalism that Law Undergraduates Should Have}

\section{They Should Have Solid Basic Knowledge of Law}

The reason that law is a practical subject, which is based on in most cases the legal occupation people provide legal services to the public in the use of their own professional knowledge of law. Therefore, mastering much professional knowledge of law is the minimum requirement that proposed for law undergraduate, and it is also the rudimental knowledge of legal occupation that the students of law should master. The basic knowledge of law can be divided into two categories, namely the abstract law basic theory knowledge and the specific legal provisions. The basic theoretical knowledge of law is foundation that being law learners constantly improve their theoretical level. Only by learning the basic theory of the system, we can truly understand the essence of the theory of law, clear legal provisions contained in the regulations, understand the value of the pursuit of law, can balance the interests and conflicts of the parties in the practice of law, and also can achieve fairness and justice of law. Moreover, we must be clear that the grassroots legal occupation, such as judges, prosecutors and lawyers and other legal provisions that the legal knowledge they use most in their daily work is the specific legal provisions. So, the undergraduate of law should be familiar with the legal provisions of knowledge.

\section{They Should Have a Firm Legal Thinking}

The cultivation of legal thinking of students is the primary goal of undergraduate education of law. The stage of undergraduate education is the stage that to develop students' basic legal literacy, so the undergraduate education of law should ensure that construct the complete system of legal theory of knowledge and formation legal thinking in the minds of students. In the process of formation legal thinking, we should strengthen the practice teaching of Law Majors. As the undergraduate major in law that has good legal occupation literacy, he or she must have a firm legal thinking, and the legal thinking performance of the firm and correct law faith and occupation ethics.

\section{They Should Have Strong Practical Ability}

In recent years, Chinese legal education and legal occupation demand disjointed problem has been reversed to some extent, but the disconnect phenomenon between the two still exists, which is a reality we should not avoid. "Legal education is not only realizing the need of training professionals of the occupation through special training, and is not only cultivating legal talents that with the ideal of law, legal ethics and language skills, legal thinking and other aspects that different from ordinary people, but also meet the need for training the persons that adapt to the society with good professional legal to solve practical problems." [4] In order to cultivate the applied legal talents occupation eligibility, the undergraduate education of law as a kind of occupation education must pay attention to training the student occupation ability. While the most important part in the occupation ability is the judicial practice ability of students. For example, the ability to use the basic theory knowledge to solve specific trial; the ability of the court debate; the ability of investigation; the ability of judicial documents drafting and writing; the ability to review the contract and so on. To improve the practical ability of students, we should strengthen the practice teaching of law education in the beginning.

\section{The Legal Talents Cultivation Path Lies in Strengthening the Occupation Quality Education}

Strengthen the occupation quality education of undergraduate of law, we should clear the training objectives of law undergraduate education, on the base of cultivating target we should design a set of scientific, reasonable and feasible occupation quality training program of undergraduate education of law. 


\section{Clear Law Undergraduate Education is Occupation Education}

In the Chinese mode of education, theoretical education and practical education is a strict distinction. Judging from the current situation, our education is a kind of knowledge education, is a kind of education with record of formal schooling. And the cultivation of student' practical skills is just some auxiliary teaching work. In Chinese current college law education, teaching theory basically occupy most of the teaching time, the classical model is the "indoctrination" of classroom teaching. The teachers just do systematic interpretation for theory, and do not teach knowledge from the practice of law subject itself, and do not think about technical training of students' practical ability and operation ability. For the emergence of this situation, the reason mainly lies in the position of college undergraduate education of law teaching in our country is not clear. The reason for the higher legal education goal is fuzzy lies in we do not recognize the occupation of legal education. Thus, in order to cultivate applied legal talents to meet the needs of society, the speciality of law in college must be clear that the occupation education is its primary teaching goal for the undergraduate law education. So, training objectives of undergraduate law in general can be expressed as: training applied talents can be engaged in legal practice and related work to adapt to the needs of the socialist market economy, who has good knowledge of law and humanities, understand the basic theory of contemporary law, methods and means, have the basic ability of legal thinking and legal research.

\section{The Students Are Classified to Cultivation}

Based on clearing the overall train objective of university undergraduate legal education is occupation education, the implementation of classification training program for university undergraduate law students will be enforced. According to the social needs and their own will, the law undergraduate students will be segmented into the academic foundation, practice and cross disciplinary three basic types, and different types of students carry out different training programs. First, training target of academic foundation of legal talent: we should abutment with Law Major Postgraduates in various disciplines, so that students in the undergraduate can master professional knowledge system, and expand the depth and breadth of learning theory, understand the basic methods of theoretical research, thus we can ensure the graduate students have the knowledge and ability to take part in the entrance exams for postgraduate schools. Second, training target of legal practice of legal personnel: the teaching should focus on training of practice teaching and practice skills. The students can grasp practical ability to solve the practical problems, besides strong legal thinking and good legal occupation accomplishment. This kind of student not only has the ability to obtain the corresponding occupation qualification examination law, also has the ability to engage in professional legal practice technical work. Third, training target cross professional compound legal talents: on the base of the legal professional core courses, relying on elective subject advantages of school and cross professional courses, training the compound management talents with the socialist concept of rule of law and other professional knowledge.

\section{Strengthen the Practical Teaching of Law Undergraduate for Occupation}

The practice of law determines that we must pay attention to the practice teaching of law. Strengthening the practice teaching of legal education, we should proceed from the following aspects:

\section{First, Construct Reasonable Practice Teaching Mode}

The practice teaching of law, generally, it refers to the specialized complex teaching settings which are assist legal theory teaching. In this part of teaching, practical ability of analyzing and solving problems of students can obtain and improve. The practice teaching of law shows in various forms, such as classroom case discussion, classroom debate, mock court, graduation practice, legal aid, legal clinic etc. Law practice teaching system can be divided into two main categories, namely the classroom practice teaching system and outside the classroom. Therefore, in the process of law education, law professional colleges should adopt to different practice teaching mode for which is 
most reasonable according to the basic situation of this profession. In practice, we should choose our legal practice teaching mode according to the specific condition, and this mode should be operational, diverse and progressive. We can gradually establish the three level training mode of practice teaching. The first level: in grade one and two, based on the legal theory knowledge, we cultivate students' legal awareness and legal awareness of sensibility combine with the case teaching method as a means of combining the court probation, etc.; The second level, in grade two and three, we should develop experimental teaching relying on legal clinic courses and the moot court to train students' occupation ability; The third level, in grade three and four, we should cultivate students' sense of social responsibility and dedication, and train students' thinking ability, expression ability through participating in the legal aid activities and summer internships.

\section{Second, Establish the Supporting System of Practice Teaching}

Law teaching practice develops smoothly need support and cooperation. First of all, in order to provide a solid foundation for the teaching practice we want to increase capital investment. The practice teaching of law needs to have sufficient financial support, such as the moot court teaching and legal clinic teaching and so on require special facilities, and these all need financial support. Secondly, ensuring the practice teaching smoothly develop we should establish a stable practice base. In general, we should take measures to combine campus with off campus practice base. University School of law should set long-term fixed practice base in the local court, procuratorate, Public Security Bureau Department and other enterprises. Thus, the college teachers and students can contact more front-line practice, realize the sharing of resources and ensure the stability and diversity of practice teaching. [5] Finally, we should improve college teachers' practical ability and provide qualified teachers for teaching practice. For the practical teaching, the guidance of teachers should not only have rich professional knowledge and teaching experience, but also have the ability to develop practice teaching and the practical experience, otherwise they will not be able to do the work well about teaching practice.

\section{Third, Perfect the Management Mechanism of the Practice Teaching of Law, Establish A Scientific Evaluation System}

Schools should establish and perfect the rules and regulations of law practice teaching management, establish practical teaching teachers incentive mechanism, thus we can arouse the enthusiasm of students and teachers to participate in teaching practice. We should strengthen all aspects of practice teaching management to ensure the stability of the teaching order of law practice. In addition, the evaluation system of teaching practice is scientific or not, which determines the quality of practice teaching. Therefore, the establishing of practical teaching evaluation system must be scientific, reasonable and feasible. And this system must be comprehensive and objective, which including the evaluation method for teachers, including the evaluation criteria for students, including the practical teaching of the curriculum is reasonable or not and whether the evaluation index of the operation is order. For the evaluation of teacher assessment, we want to realize that the task performance effect the teacher's promotion and allowance, thus we can promote the enthusiasm of teaching practice. Especially for students to participate in the examination of the practice teaching, we should achieve specific quantitative assessment. For example, we can specify the time of know practice not less than 2 months that the students need to be done each year, and the internship report must have the evaluation results coming from the instructor, so we can ensure that the time and the effect of students joining in teaching practice.

\section{Summary}

We believe that by strengthening the occupation quality education of law undergraduates, we will be able to cultivate legal application talents with high quality to meet the social need, and this is also provides a basic premise for enhancing the law students' employment rate. 


\section{Acknowledgement}

This research was financially supported by the key issue of teaching reform project of Beihua University in 2017 "the study on law undergraduates occupation quality education of local university".

\section{References}

[1] Xian-Dan Huo, Legal talent is the first resource of building the rule of law, Jia-Hong He, Jin-Guang $\mathrm{Hu}$, Legal personnel and judicial reform -- dialogue between Japanese and Chinese jurists, China procuratorial press,(2003)37.

[2] Li-huan Zhu, The basic idea of Chinese legal education reform, Law Science Magazine, vol.1, (2008).

[3]Xian-Dan Huo, The historical mission and repositioning of legal education, Political and Legal Forum, vol.4, (2004).

[4] Ming $\mathrm{Hu}$, The sporting theory of justice, legal realism and legal clinic education-— from Yale's traditional legal realism, legal science, vol.3, (2011)47.

[5] Wei-Min Shi, Some thoughts on improving the practice teaching of law major in China, Journal of Chengdu University, vol.7, (2008). 